\title{
Hypothyroidism attenuates protein tyrosine nitration, oxidative stress and renal damage induced by ischemia and reperfusion: effect unrelated to antioxidant enzymes activities
}

Verónica M Tenorio-Velázquez ${ }^{1,2}$, Diana Barrera ${ }^{3}$, Martha Franco ${ }^{2}$, Edilia Tapia ${ }^{2}$, Rogelio Hernández-Pando ${ }^{4}$, Omar Noel Medina-Campos ${ }^{1}$ and José Pedraza-Chaverri*1

Address: ${ }^{1}$ Facultad de Química, Departamento de Biología, Edificio B, Segundo Piso, Laboratorio 209, Universidad Nacional Autónoma de México (UNAM), Ciudad Universitaria, 04510, México, D.F., México, ²Departamento de Nefrología, Instituto Nacional de Cardiología "Ignacio Chávez", Juan Badiano \#1, Col. Sección XVI, 14080, Tlalpan, México, D.F., México, ${ }^{3}$ Facultad de Medicina, Departamento de Farmacología, Universidad Nacional Autónoma de México (UNAM), Ciudad Universitaria, 04510, México, D.F., México and ${ }^{4}$ Instituto Nacional de Ciencias Médicas y Nutrición "Salvador Zubirán", Departamento de Patología, 14000, México, D.F., México

Email: Verónica M Tenorio-Velázquez - moni_teve@yahoo.com.mx; Diana Barrera - dianabarrera@hotmail.com; Martha Franco - marthafranco@lycos.com; Edilia Tapia - ediliatapia@hotmail.com; Rogelio Hernández-Pando - rhdezpando@hotmail.com; Omar Noel Medina-Campos - mconoel@servidor.unam.mx; José Pedraza-Chaverri* - pedraza@servidor.unam.mx

* Corresponding author

Published: 07 November 2005

BMC Nephrology 2005, 6:12 doi:10.1 186/147|-2369-6-12

This article is available from: http://www.biomedcentral.com/I47I-2369/6/12

(C) 2005 Tenorio-Velázquez et al; licensee BioMed Central Ltd.

This is an Open Access article distributed under the terms of the Creative Commons Attribution License (http://creativecommons.org/licenses/by/2.0), which permits unrestricted use, distribution, and reproduction in any medium, provided the original work is properly cited.

\begin{abstract}
Background: It has been established that hypothyroidism protects rats against renal ischemia and reperfusion (IR) oxidative damage. However, it is not clear if hypothyroidism is able to prevent protein tyrosine nitration, an index of nitrosative stress, induced by IR or if antioxidant enzymes have involved in this protective effect. In this work it was explored if hypothyroidism is able to prevent the increase in nitrosative and oxidative stress induced by IR. In addition the activity of the antioxidant enzymes catalase, glutathione peroxidase, and superoxide dismutase was studied. Control and thyroidectomized (HTX) rats were studied $24 \mathrm{~h}$ of reperfusion after $60 \mathrm{~min}$ ischemia.

Methods: Male Wistar rats weighing $380 \pm 22 \mathrm{~g}$ were subjected to surgical thyroidectomy. Rats were studied 15 days after surgery. Euthyroid sham-operated rats were used as controls (CT). Both groups of rats underwent a right kidney nephrectomy and suffered a 60 min left renal ischemia with $24 \mathrm{~h}$ of reperfusion. Rats were divided in four groups: CT, HTX, IR and HTX+IR. Rats were sacrificed and samples of plasma and kidney were obtained. Blood urea nitrogen (BUN) and creatinine were measured in blood plasma. Kidney damage was evaluated by histological analysis. Oxidative stress was measured by immunohistochemical localization of protein carbonyls and 4hydroxy-2-nonenal modified proteins. The protein carbonyl content was measured using antibodies against dinitrophenol (DNP)-modified proteins. Nitrosative stress was measured by immunohistochemical analysis of 3-nitrotyrosine modified proteins. The activity of the antioxidant enzymes catalase, glutathione peroxidase, and superoxide dismutase was measured by spectrophotometric methods. Multiple comparisons were performed with ANOVA followed by Bonferroni $t$ test.
\end{abstract}


Results: The histological damage and the rise in plasma creatinine and BUN induced by IR were significantly lower in HTX+IR group. The increase in protein carbonyls and in 3-nitrotyrosine and 4-hydroxy-2-nonenal modified proteins was prevented in HTX+IR group. IR-induced decrease in renal antioxidant enzymes was essentially not prevented by $H T X$ in $H T X+I R$ group.

Conclusion: Hypothyroidism was able to prevent not only oxidative but also nitrosative stress induced by IR. In addition, the antioxidant enzymes catalase, glutathione peroxidase, and superoxide dismutase seem not to play a protective role in this experimental model.

\section{Background}

Reactive oxygen species (ROS) $[1,2]$ and reactive nitrogen species such as peroxynitrite (ONOO-) [3] are involved in the damage induced by ischemia and reperfusion (IR). The damage by reactive nitrogen species has been made evident by the increase in protein tyrosine nitration [3-6]. The consequences of IR include alterations in DNA, lipids, and proteins (carbonyl formation and nitrosylation) [3$6]$. Renal IR is associated with acute renal failure $[3,4]$ as well as proximal tubular damage [1-3]. IR-induced damage is ameliorated by spin traps [2], inhibition of inducible nitric oxide synthase [3], lecithinized superoxide dismutase (SOD) [3], ebselen, a ONOO- scavenger [3], inhibitors of calpain activation [4], SOD and catalase (CAT) mimetic [6], antioxidants [7,8], or in the other circumstances such as hypothyroidism [9]. Paller [9] found that the renal damage and the increase in malondialdehyde (MDA) induced by IR were significantly lower in hypothyroid than in euthyroid rats. The specific mechanisms involved in the protective effect of hypothyroidism against renal IR remain to be fully elucidated.

The role of antioxidant enzymes in the oxidative damage to kidney has been studied. It has been found that the elevated expression of antioxidant enzymes including CAT, SOD, glutathione peroxidase (GPx) [10-15], and more recently heme oxygenase-1 $[16,17]$, prior to renal oxidant insult, was able to ameliorate renal damage. Furthermore, the inhibition of CAT [18] or heme oxygenase-1 [16] aggravates renal damage induced by puromycin aminonucleoside [18] or IR [16], respectively. These data strongly suggest that the modulation of the antioxidant enzymes may alter the renal damage induced by oxidants. It is unknown if the antioxidant enzymes may be regulated differentially and involved in the protective effect of hypothyroidism against renal IR. Interestingly, the administration of some exogenous antioxidants is able to mod- ulate antioxidants enzymes and renal damage induced by IR [19-21]. In addition, (-)-epicatechin 3-O-gallate [22] and Wen-Pi-Tang [23] induced renal antioxidant enzymes and protected against lipopolysaccharide- and IR-induced kidney damage and plasma 3-nitrotyrosine (3-NT) formation. Tyrosine nitration may be induced not only by $\mathrm{ONOO}^{-}$, but also by another reactive nitrogen species including nitrogen dioxide radical $\left(\mathrm{NO}_{2}{ }^{\circ}\right)$ and dinitrogen trioxide $\left(\mathrm{N}_{2} \mathrm{O}_{3}\right)$. ONOO- is a potent oxidation species that have been found to cause also lipid peroxidation and cytotoxicity [24-26].

Based on the above information, in the present paper we evaluated if hypothyroidism is able to prevent against the nitrosative stress induced by IR. Nitrosative stress was evaluated by measuring nitrated proteins by immunohistochemistry using antibodies against 3-NT $[3-6,27,28]$. Oxidative stress was evaluated using immunohistochemical techniques to evaluate the protein carbonyl content [29] and 4-hydroxy-2-nonenal (4-HNE) protein adducts $[30,31]$. The protein carbonyl content was measured using antibodies against dinitrophenol (DNP)-modified proteins [29]. In addition the activity of the antioxidant enzymes CAT, GPx, and SOD was studied before and after renal IR in control and hypothyroid rats.

\section{Methods \\ Reagents}

Xanthine, nitroblue tetrazolium (NBT), 3,3-diaminobenzidine, bovine serum albumin, xanthine oxidase, $\mathrm{NADPH}$, glutathione reductase (GR), 2,4-dinitrophenylhydrazine, and reduced glutathione (GSH) were purchased from Sigma (St. Louis, MO, USA). Ethylenediaminetetraacetic acid disodium salt (EDTA $\mathrm{Na}_{2}$ ), ammonium sulfate, and copper chloride were purchased from JT Baker (Mexico City, México). Hydrogen peroxide $\left(\mathrm{H}_{2} \mathrm{O}_{2}\right)$, formaldehyde, and sodium carbonate

Table I: Plasma creatinine and BUN in the four groups of rats studied.

\begin{tabular}{lllll}
\hline & CT & HTX & IR & HTX+IR \\
\hline Creatinine, mg/dL & $0.45 \pm 0.05$ & $0.40 \pm 0.08$ & $5.08 \pm 0.55^{\mathrm{a}}$ & $3.83 \pm 0.4 \mathrm{I}^{*}$ \\
BUN, mg/dL & $26 \pm 2$ & $23 \pm 1$ & $122 \pm 1 \mathrm{I}^{\mathrm{a}}$ & $78 \pm 17^{*}$ \\
\hline
\end{tabular}

Data are mean $\pm S D . N=16$. aP $<0.001$ vs. $C T, * P<0.001$ vs. IR. 

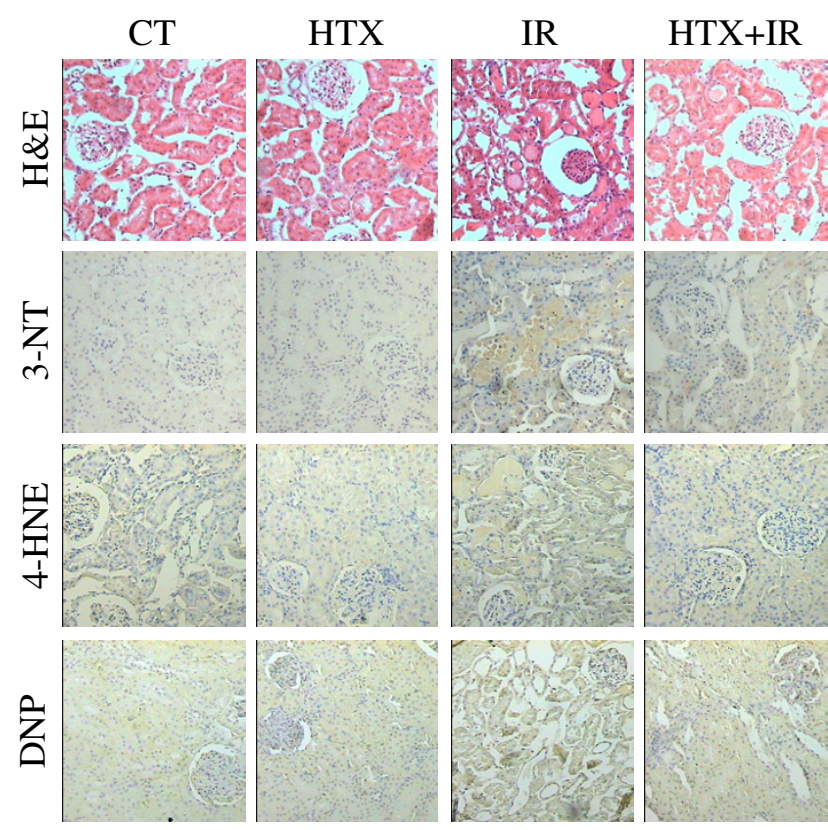

Figure I

Representative images of histology (H\&E) (first row) and immunohistochemical detection of 3-NT (second row), 4HNE (third row) and DNP (fourth row) in the renal cortex of the four groups of rats studied: Control (CT), thyroidectomized (HTX), ischemia and reperfusion (IR) and HTX+IR (I00× magnification).

were obtained from Mallinckrodt (Paris, KY, USA). Sodium azide was obtained from Merck (Mexico City, México). Rabbit anti-3-NT polyclonal antibodies were from Upstate (Catalogue \# 06-284, Lake Placid, NY, USA). Goat anti-DNP polyclonal antibodies (Catalogue \# J06) were from Biomeda Corporation (Foster City, CA, USA). Mouse anti-4-HNE monoclonal antibodies (Catalogue \#24325) were from Oxis International Inc. (Portland, OR, USA). Anti-rabbit Ig horseradish peroxidase antibody (Catalogue \# NA-934) and anti-mouse Ig horseradish peroxidase antibody (Catalogue \# NIF-825) were purchased from Amersham Life Sciences (Buckinghamshire, England). Donkey anti-goat horseradish peroxidase antibodies (Catalogue \# SC2020) were from Santa Cruz Biotechnology, Inc. (Santa Cruz, CA, USA). All other chemicals were reagent grade and commercially available.

\section{Induction of hypothyroidism}

All animal procedures were approved by the Animal Care Committee of the Instituto Nacional de Cardiología "Ignacio Chavez" and followed the guidelines of Norma Oficial Mexicana (NOM-ECOL-087-1995). Male Wistar rats weighing $380 \pm 17 \mathrm{~g}$ underwent surgical thyroidectomy with parathyroid reimplant (HTX), as previously

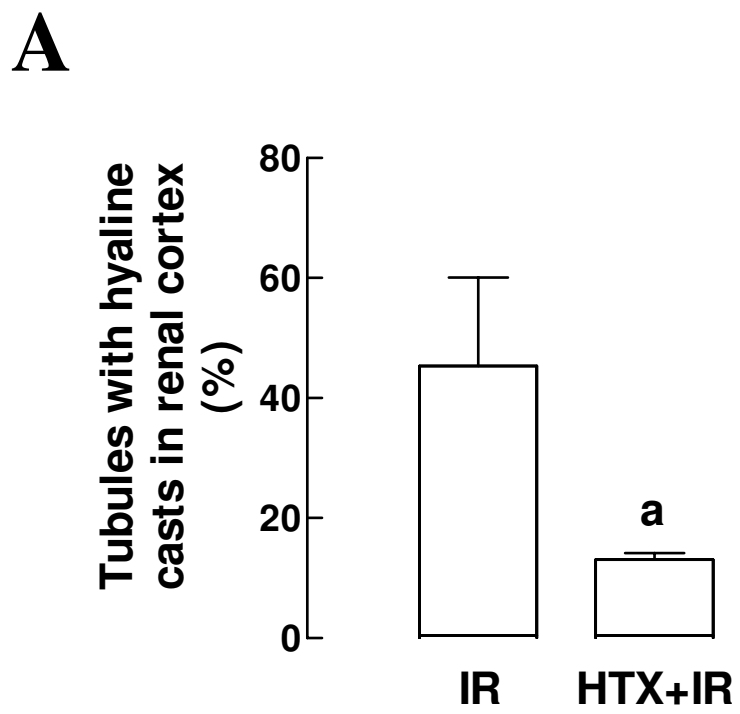

B

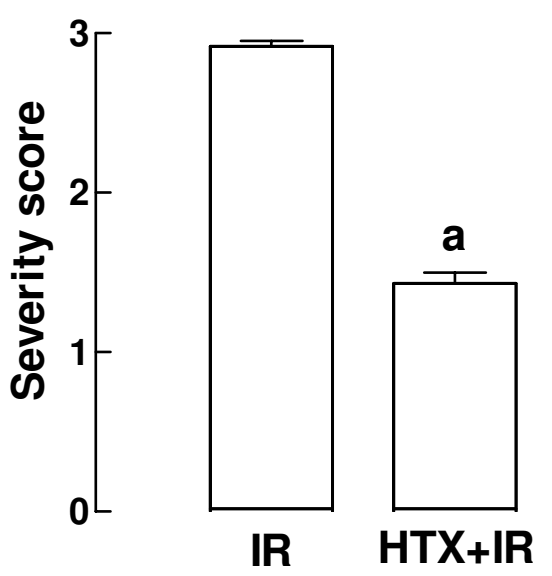

Figure 2

Quantitative analysis of damage in the renal cortex of rats from IR and HTX+IR groups. (A) Percentage of tubules with hyaline casts. $n=4$ rats and 60 tubuli/rat. (B). Severity score. Mean \pm SD. $n=4$ rats and I 5 tubuli/rat. aP $<0.00$ I vs. IR.

described [32-35]. Briefly, the trachea was exposed under ether anesthesia, and under a stereoscopic microscope (Wild M5, Wild Heerbrugg, Switzerland), the parathyroid glands were visualized, dissected from the thyroid gland, and reimplanted into the surrounding neck muscles. The thyroid gland was then carefully dissected, to avoid injury to the laryngeal nerves, and completely excised. The effectiveness of this procedure was assessed by determining the concentration of calcium, phosphorous and thyroxine in 10 sham-operated control and 10 HTX rats, using stand- 
A

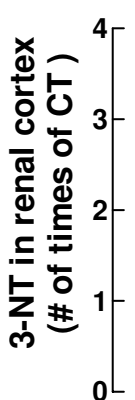

B

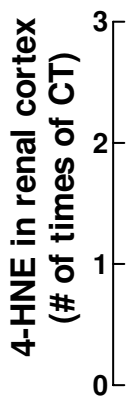

C

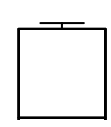

CT

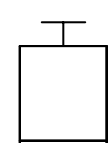

HTX

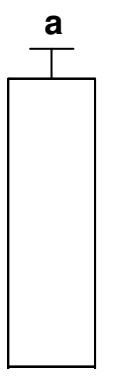

IR HTX+IR

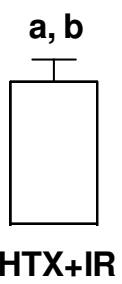

A

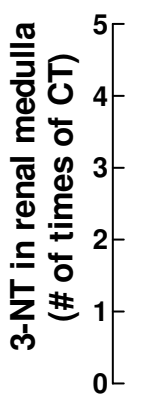

B
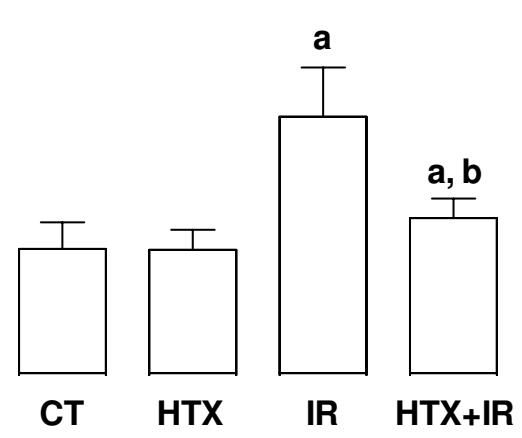

CT HTX
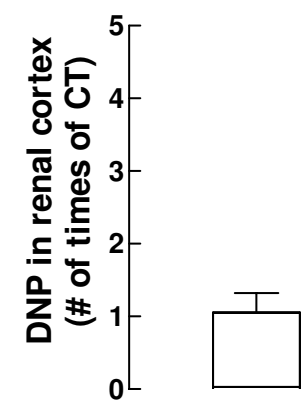

CT
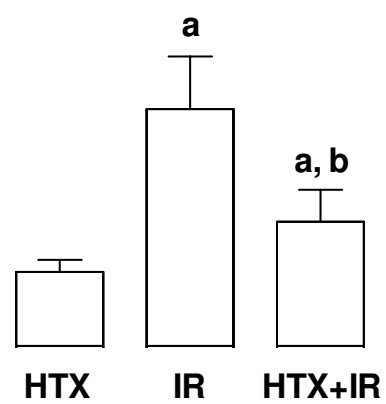

Figure 3

Quantitative immunostaining of 3-NT, 4-HNE, and DNPmodified proteins in renal cortex of the four groups of rats studied: CT, HTX, IR, and HTX+IR. $n=4$ rats and 10 determinations/rat. Mean \pm SD. aP $<0.001$ vs. control, bP $<0.00$ I vs. IR.

ard techniques. The results obtained 15 days after surgery were: $\mathrm{Ca}^{2+}$ of $10.2 \pm 3$ in control vs. $10.3 \pm 0.2 \mathrm{mM}$ in HTX; phosphorous of $6.5 \pm 0.3$ in control vs. $6.3 \pm 0.5 \mathrm{mM}$ in HTX; and thyroxine of $6.4 \pm 0.77$ in control vs. $1.18 \pm 0.19$ $\mu \mathrm{g} \mathrm{dL}^{-1}$ in HTX, $\mathrm{P}<0.05$. The sham group $(375 \pm 14 \mathrm{~g})$ underwent a surgical procedure in which the animals were anesthetized, the trachea was exposed and then the incision was closed simulating the thyroidectomy surgery. 


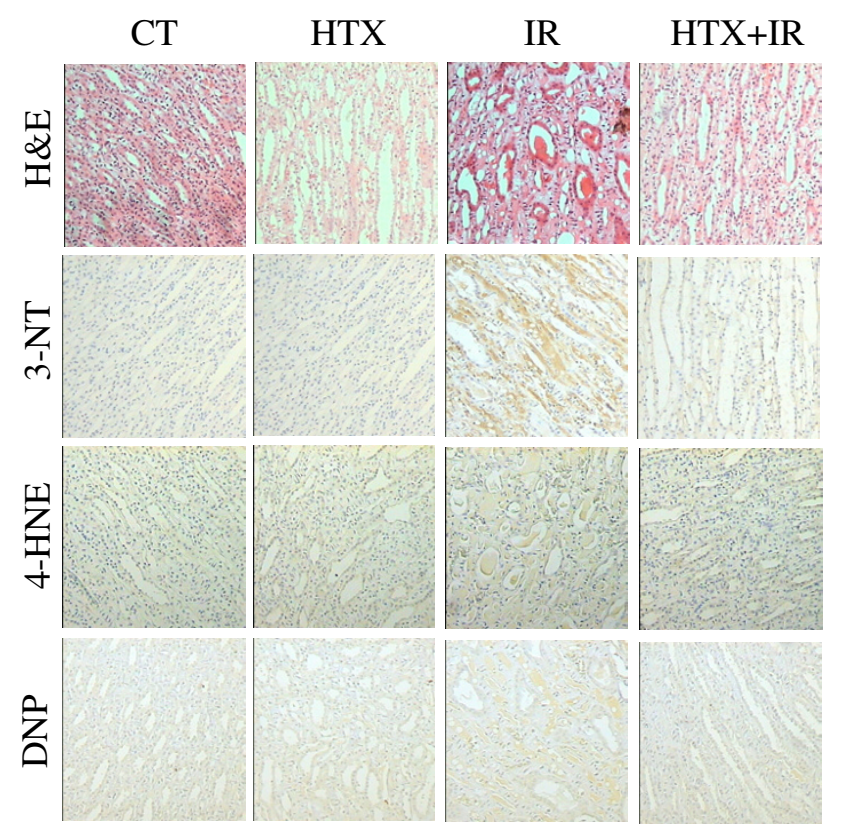

Figure 4

Representative images of histology (H\&E) (first row) and immunohistochemical detection of 3-NT (second row), 4HNE (third row) and DNP (fourth row) in renal medulla of the four groups of rats studied: CT, HTX, IR, and HTX+IR. (I00× magnification).

The body weight for HTX and CT rats obtained 15 days after surgery was $389 \pm 22 \mathrm{~g}$ and $417 \pm 25 \mathrm{~g}$, respectively.

\section{Ischemia and reperfusion studies}

Four groups of rats were studied: Control (CT), sham operated animals; hypothyroid (HTX), rats subjected to thyroidectomy; ischemia and reperfusion (IR), rats submitted to IR; and HTX+IR, rats subjected to HTX plus IR. The experimental protocol was performed 15 days after the thyroidectomy (HTX group) or the simulated surgery (CT). Under anesthesia and heparin administration, blood samples were obtained and the kidneys were reperfused and removed. Additional animals from CT and HTX groups were subjected to right nephrectomy and the left renal artery was occluded with a non-traumatic vascular clamp for $60 \mathrm{~min}$. Then, the clamp was released allowing the reestablishment of renal blood flow or reperfusion and $24 \mathrm{~h}$ after the rats were anesthetized, blood samples were obtained and the kidney was washed with $0.9 \%$ saline solution and excised. These groups were named as IR and HTX+IR, respectively. Blood plasma was obtained and stored at $-40^{\circ} \mathrm{C}$. Kidney was used for histological and immunohistochemical studies and for determination of antioxidant enzymes activities. Areas of the kidney (renal

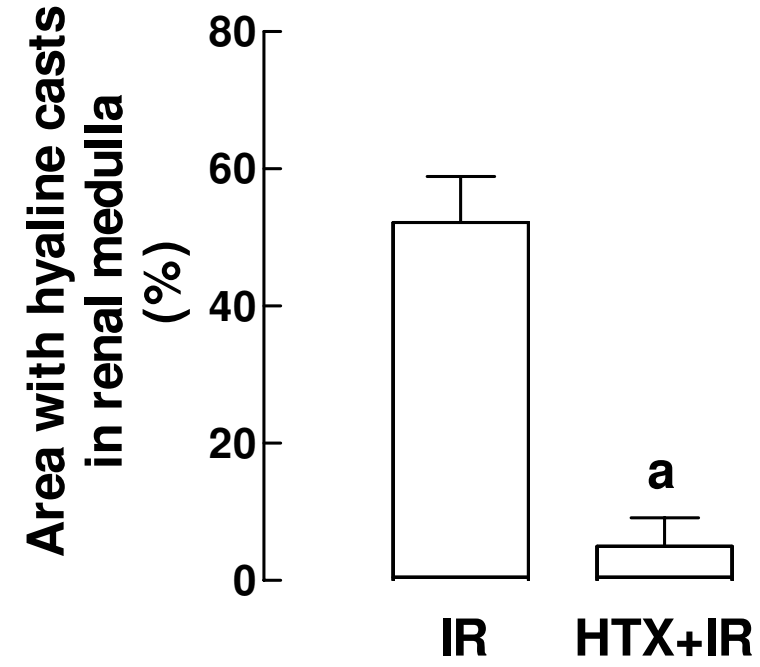

Figure 5

Quantitative analysis of damage in the renal medulla of rats from IR and HTX+IR groups. Area of tubular lumen with hyaline casts is shown as percentage. $n=4$ rats, and 60 tubular lumen/rat. Mean \pm SD. aP $<0.00$ I vs. IR.

cortex, outer medulla and inner medulla) were macroscopically dissected using a razor blade and frozen at $70^{\circ} \mathrm{C}$ for further measurement of enzymatic activities.

\section{Determination of plasma creatinine and blood urea nitrogen (BUN)}

Creatinine and BUN were measured using a creatinine analyzer model 2 and a BUN analyzer 2 (Beckman Instruments, Fullerton, CA, USA), respectively.

\section{Histological studies}

Kidney tissue slices were fixed in 10\% neutral buffered formaldehyde solution, and embedded in paraffin $[27,36,37]$. Sections at $4 \mu \mathrm{m}$ of thickness were obtained and stained with hematoxylin-eosin (H\&E). Histologic assessment of tubular necrosis was determined semiquantitatively using a method described by Chatterjee et al. [38]. The score was graded from 0 to 3 where $0=$ normal histology, 1 = tubular cells swellings, brush border loss, nuclear condensation, with up to one third of tubular profile showing nuclear loss; 2 = same as for score, but greater than one third and less than two thirds of tubular profile shows nuclear loss; 3 = grater of two thirds of tubular profile shows nuclear loss. In addition a quantitative histological damage was determined by using a Leica Qwin Image Analyzer (Leica Microsystems, Cambridge, UK). The following parameters were quantified: (a) the percentage of tubules with hyaline casts in the renal cortex, using the low power magnification objective, three ran- 
Table 2: Catalase activity ( $\mathrm{k} / \mathrm{mg}$ protein) in the four groups of rats studied.

\begin{tabular}{lllll}
\hline & CT & HTX & IR & HTX+IR \\
\hline Renal cortex & $0.22 \pm 0.04(16)$ & $0.22 \pm 0.02(16)$ & $0.17 \pm 0.05^{\mathrm{a}}(5)$ & $0.14 \pm 0.04^{\mathrm{b}}(5)$ \\
Outer medulla & $0.07 \pm 0.02(16)$ & $0.08 \pm 0.02(16)$ & $0.08 \pm 0.017(7)$ & $0.04 \pm 0.004 \mathrm{~b}, *(7)$ \\
Inner medulla & $0.013 \pm 0.002(16)$ & $0.014 \pm 0.003(16)$ & $0.012 \pm 0.003(7)$ & $0.012 \pm 0.002(7)$ \\
\hline
\end{tabular}

Data are mean $\pm S D$. Number of determinations is in parentheses. aP $<0.05$ vs. $C T$, $b P<0.00$ I vs. $H T X$, $* P<0.0 I$ vs IR.

dom choice fields were studied counting the tubules without and with hyaline casts to determine the percentage of the latter, and (b) in those tubules with hyaline casts, the total lumen area and the area occupied by the cast were determined, then the percentage of the lumen area occupied by the hyaline cast was determined.

\section{Immunohistochemical localization of 3-NT, DNP, and 4- HNE}

For immunohistochemistry, $4 \mu \mathrm{m}$ sections were deparaffinized with xylene and rehydrated with ethanol. Endogenous peroxidase was quenched/inhibited with $4.5 \%$ $\mathrm{H}_{2} \mathrm{O}_{2}$ in methanol by incubation for $1.5 \mathrm{~h}$ at room temperature. The sections used for DNP immunohistochemistry were incubated with $0.2 \%$ dinitrophenylhydrazine in $2 \mathrm{~N} \mathrm{HCl}$ for $60 \mathrm{~min}$ at room temperature in absence of light and then were extensively washed. Nonspecific adsorption was minimized by leaving the sections in 3\% bovine serum albumin in phosphate buffer saline for 30 min. Sections were incubated overnight with 1:700 dilution of anti-3-NT antibody [36] or with 1:500 dilution of anti-DNP antibody or with 1:100 dilution of anti-4-HNE antibody [36]. After extensive washing with phosphate buffer saline, the sections were incubated with 1:500 dilution of peroxidase conjugated anti-rabbit Ig antibody (for 3-NT) or with a 1:500 dilution of a peroxidase conjugated anti-goat Ig or anti-mouse IgG (for DNP and 4-HNE, respectively) for $1 \mathrm{~h}$, and finally incubated with $\mathrm{H}_{2} \mathrm{O}_{2}$ diaminobenzidine for $1 \mathrm{~min}$. Sections were counterstained with hematoxylin (for 3-NT and 4-HNE) or with methyl green (for DNP) and observed under light microscopy. All the sections from the four studied groups were incubated under the same conditions with the same antibodies concentration, and in the same running, so the immunostaining was comparable among the different experimental groups. Quantitative image analysis was performed with a Zeiss KS 300 Imaging System 3.0 (Carl Zeiss Vision GmbH, Hallbergmoos, Germany). This software determines densitometric means value of selected tissue regions. Thus, 10 fields/rat were randomly selected and the intensity of the 3-NT, 4-HNE, and DNP immunostaining was determined. We normalized the data (arbitrary units) to 1.0 using the control kidneys. We run negative controls omitting primary and/or secondary antibodies.

\section{Tissue homogenization}

Renal cortex, outer medulla and inner medulla were homogenized in a Polytron (Model PT 2000, Brinkmann, Westbury, NY, USA) for 10 seconds in cold $50 \mathrm{mM}$ potassium phosphate, $0.1 \%$ Triton $\mathrm{X}-100, \mathrm{pH}=7.0$ [28]. The homogenate was centrifuged at $19,000 \times \mathrm{g}$ and $4^{\circ} \mathrm{C}$ for 30 min and the supernatant was separated to measure total protein and the activities of CAT, GPx, and SOD. Total protein was measured by the method of Lowry et al. [39].

\section{Catalase assay}

Renal CAT activity was assayed at $25^{\circ} \mathrm{C}$ by a method based on the disappearance of $\mathrm{H}_{2} \mathrm{O}_{2}$ from a solution containing $30 \mathrm{mM} \mathrm{H}_{2} \mathrm{O}_{2}$ in $10 \mathrm{mM}$ potassium phosphate buffer pH 7.0 at $240 \mathrm{~nm}$ [40]. The reaction was started by the addition of $25 \mu \mathrm{L}$ of the sample to $725 \mu \mathrm{L}$ of $\mathrm{H}_{2} \mathrm{O}_{2}$. Under the described conditions, the decomposition of $\mathrm{H}_{2} \mathrm{O}_{2}$ by CAT contained in the samples follows a firstorder kinetic as given by the equation $\mathrm{k}=2.3 / \mathrm{t} \log \mathrm{Ao} / \mathrm{A}$ where $\mathrm{k}$ is the first-order reaction rate constant, $\mathrm{t}$ is the time over which the decrease of $\mathrm{H}_{2} \mathrm{O}_{2}$, due to CAT activity, was measured (15 s), and Ao/A is the optical density at times 0 and $15 \mathrm{~s}$, respectively. The results were expressed in $\mathrm{k} / \mathrm{mg}$ protein.

\section{Glutathione peroxidase assay}

Renal GPx activity was assayed by a method previously described [41]. Reaction mixture consisted of $50 \mathrm{mM}$ potassium phosphate $\mathrm{pH}=7.0,1 \mathrm{mM}$ EDTA, $1 \mathrm{mM}$ sodium azide, $0.2 \mathrm{mM} \mathrm{NADPH}, 1 \mathrm{U} / \mathrm{mL}$ of glutathione reductase, and $1 \mathrm{mM}$ GSH. One hundred $\mu \mathrm{L}$ of the appropriate dilution of tissue homogenates were added to 0.8 $\mathrm{mL}$ of mixture and allowed to incubate for $5 \mathrm{~min}$ at room temperature before initiation of the reaction by the addition of $0.1 \mathrm{~mL} 2.5 \mathrm{mM} \mathrm{H}_{2} \mathrm{O}_{2}$ solution. Absorbance at 340 $\mathrm{nm}$ was recorded for $3 \mathrm{~min}$ and the activity was calculated from the slope of these lines as $\mu$ moles of NADPH oxidized per min taking into account that the millimolar absorption coefficient for NADPH is $6.22 \mathrm{mM}^{-1} \mathrm{~cm}^{-1}$. Blank reactions with homogenates replaced by distilled water were subtracted from each assay. The results were expressed as $\mathrm{U} / \mathrm{mg}$ protein.

\section{Superoxide dismutase assay}

SOD activity in kidney homogenates was assayed by using a previously reported method [41]. A competitive inhibi- 
Table 3: Glutathione peroxidase activity (U/mg protein) in three sections of kidney from the four groups of rats studied.

\begin{tabular}{lllll}
\hline & CT & HTX & IR & HTX+IR \\
\hline Renal cortex & $0.10 \pm 0.01(16)$ & $0.11 \pm 0.01(16)$ & $0.07 \pm 0.03^{\text {a }}(7)$ & $0.04 \pm 0.0 I^{b, * *}(7)$ \\
Outer medulla & $0.07 \pm 0.01(16)$ & $0.06 \pm 0.01 *(16)$ & $0.03 \pm 0.003^{\mathrm{a}}(7)$ & $0.05 \pm 0.007^{* * * *}(7)$ \\
Inner medulla & $0.06 \pm 0.02(16)$ & $0.05 \pm 0.01(16)$ & $0.05 \pm 0.02(6)$ & $0.03 \pm 0.003(6)$ \\
\hline
\end{tabular}

Data are mean $\pm S D$. Number of determinations is in parentheses. aP $<0.001$ vs. $C T$, bP $<0.001$ vs. $H T X,{ }^{*} P<0.05$, vs. $C T$, ${ }^{* * P}<0.01$, $* * * P<0.00 I$ vs. IR.

tion assay was performed using xanthine-xanthine oxidase system to reduce NBT. Mixture reaction contains in a final concentration: $0.122 \mathrm{mM}$ EDTA, $30.6 \mu \mathrm{M}$ NBT, $0.122 \mathrm{mM}$ xanthine, $0.006 \%$ bovine serum albumin, and $49 \mathrm{mM}$ sodium carbonate. Five hundred $\mu \mathrm{L}$ of tissue homogenate at the appropriate dilution, were added to $1.66 \mathrm{~mL}$ of the mixture described above, then $50 \mu \mathrm{L}$ xanthine oxidase, in a final concentration of $2.8 \mathrm{U} / \mathrm{L}$, were added and incubated in a water bath at $27^{\circ} \mathrm{C}$ for $30 \mathrm{~min}$. The reaction was stopped with $066 \mathrm{~mL}$ of $0.8 \mathrm{mM}$ cupric chloride and the optical density was read at $560 \mathrm{~nm}$. One hundred percent of NBT reduction was obtained in a tube in which the sample was replaced by distilled water. The amount of protein that inhibited NBT reduction to $50 \%$ of maximum was defined as one unit of SOD activity. Results were expressed as U/mg protein.

\section{Statistics}

The data are expressed as the mean \pm SD. Data were analyzed with a non-paired t-test or with ANOVA followed by multiple comparisons by Bonferroni t test, as appropriate. $P$ value less than 0.05 was considered statistically significant.

\section{Results}

\section{General and biochemical data}

Creatinine and BUN were similar in CT and HTX groups (Table 1). Twenty four h after IR, both plasma creatinine and BUN increased significantly, however the increases were significantly lower in HTX+IR group (Table 1). These data confirm previous observations of Paller [9] who showed that the renal damage induced by IR was ameliorated in HTX rats.

\section{Histological and immunohistochemical analysis}

Representative histopathology and immunohistochemistry features in the kidney cortex of rats after $24 \mathrm{~h}$ of IR in control and HTX rats are presented in Figure 1. Surgical induced hypothyroidism does not produce any histological abnormality in the kidney. After IR, the kidney cortex shows extense ischemic tubular necrosis and hyaline cylinders are present in many tubular lumens (Figures 1 and 2).
The histological abnormalities, manifested by numerous necrotic tubules with a high percentage of tubules with hyaline casts, were significantly lower in the HTX+IR group (HTX+IR group vs. IR group $\mathrm{P}<0.001$, Figure 2 ) confirming that hypothyroidism prevented renal damage induced by IR (Figure 1). In a similar fashion than in CT rats, the immunostaining of 3-NT, 4-HNE, and DNP is negative in HTX rats, while it is strong in the IR group (Figure 3). The increase in 3-NT, 4-HNE, and DNP staining induced by IR was ameliorated in the HTX+IR group (Figures 1 and 3 ).

Representative histopathology and immunohistochemistry features in the medulla of the kidney rats in the four groups of animals is presented in Figure 4. There are no abnormalities in the renal medulla in HTX group. After IR, the kidney medulla shows extense ischemic tubular necrosis, and numerous tubular lumens have hyaline casts (Figure 4). Ischemia and reperfusion in HTX rats produced lesser histological damage, occasional medullar kidney tubules are revisted by necrotic epithelium (Figure 4) and a decrease in the area of tubular lumen occupied with hyaline casts (HTX+IR group vs. IR group, $\mathrm{P}<0.001$, Figure $5)$. Like in control rats, the immunostaining of 3-NT, 4HNE and DNP is negative in HTX rats, whereas it is strong after IR (Figure 4). The staining of 3-NT, HNE and DNP in HTX was significantly lower in HTX+IR group compared to IR group (Figures 4 and 6).

\section{Renal activity of antioxidant enzymes}

The renal activity of antioxidant enzymes in CT and HTX rats before and after IR is shown in tables 2, 3, 4. Activities of CAT (Table 2) and GPx (Table 3) were measured in renal cortex and outer and inner medulla. Superoxide dismutase was measured in renal cortex and outer medulla (Table 4). There was no enough sample of inner medulla to measure SOD. With one exception (a marginal increase in GPx activity in outer medulla), the comparisons between CT and HTX rats were not significant. Ischemia and reperfusion induced a decrease in the antioxidant enzymes. Catalase activity was decreased in renal cortex of IR group compared to CT group and in renal cortex and outer medulla of HTX+IR group compared to HTX group 
Table 4: Superoxide dismutase activity (U/mg protein) in the four groups of rats studied.

\begin{tabular}{lllll}
\hline & CT & HTX & IR & HTX+IR \\
\hline Renal cortex & $13.3 \pm 1.0(16)$ & $14.4 \pm 1.0(16)$ & $15.1 \pm 2.1(7)$ & $13.4 \pm 3.2(7)$ \\
Outer medulla & $10.9 \pm 1.3(16)$ & $10.4 \pm 1.1(16)$ & $8.2 \pm 1.2^{\mathrm{a}(8)}$ & $5.6 \pm 1.5^{\mathrm{b}, *}(8)$ \\
\hline
\end{tabular}

Data are mean $\pm S D$. Number of determinations is in parentheses. aP $<0.001$ vs. $C T$, bP $<0.001$ vs. $H T X, * P<0.00 I$ vs. IR.

(Table 2). Glutathione peroxidase activity decreased in renal cortex and outer medulla of IR group compared to CT group and in renal cortex and inner medulla of HTX+IR group compared to HTX group (Table 3). Superoxide dismutase activity decreased in outer medulla of HTX+IR group compared to HTX group (Table 4). With one exception (GPx in outer medulla) the IR-induced decrease in renal antioxidant enzymes was not prevented by HTX in HTX+IR group. In fact, the activities of antioxidant enzymes were significantly lower in HTX+IR group than in IR group. This may suggest that the antioxidant enzymes in outer medulla HTX group are more susceptible to inactivation by IR than those of CT rats.

\section{Discussion}

The data presented in this work show that hypothyroid rats were significantly more resistant to IR induced renal damage than euthyroid rats and are consistent with the protective effect of hypothyroidism against oxidative stress and tissue damage in several experimental models [42-44]. The protective effect of HTX was observed by histological (necrotic tubules, percentage of tubules with hyaline casts and area of tubular lumen occupied by hyaline casts) and biochemical (creatinine and BUN) analyses. In addition, this protective effect was associated with a decrease in oxidative damage which was evaluated by the immunohistochemical localization of protein carbonyls and 4-HNE modified proteins. The protective effect of HTX in ischemia and reperfusion associated with the amelioration of oxidative damage had been observed previously by Paller [9]. Although hypothyroidism protects the kidney during IR, the mechanism involved in this protective effect has not been completely elucidated. One of the major effects of thyroid hormones is to increase mitochondrial respiration [45] which results in increased generation of ROS, leading to oxidative damage to membrane lipids. There is a good deal of evidence to indicate that metabolic depression brought about by hypothyroidism is associated with a decrease in free radical production and a subsequent protection against lipid peroxidation $[46,47]$. This supports the notion that reduced demand for oxygen in hypothyroidism serves as a protective factor in tissue injury due to ROS. In fact, it has been shown that hypothyroidism is able to prevent the increase in lipid peroxidation and the diminution in GSH as well the tissue damage induced by intracolonic administration of trinitrobenzene sulfonic acid (experimental model of colitis)
[42]. Hypothyroidism also prevents the increase in MDA and decreases the susceptibility to oxygen radical-induced lung damage in newborn rats exposed to prolonged hyperoxia [43]. The lower toxicity of arsenic in hypothyroid animals was associated with the prevention of arsenic-induced lipid peroxidation in liver and kidneys [44]. Furthermore, hypothyroidism was able to protect against acetaminophen hepatotoxicity [48] which has been associated to oxidative stress [49]. The majority of the studies in hypothyroid animals have found no change or a decrease in tissue markers of oxidative stress (thiobarbituric acid reactive substances, MDA or oxidized glutathione) (Table 5) supporting a decreased production of ROS in this experimental model.

In this study we also showed that IR damage was associated with an increase in tyrosine nitration which is consistent with previous studies [3-6]. Interestingly, it was observed that the protective effect of HTX was associated with a significant decrease in 3-NT immunostaining. Noiri et al. [3], Chatterjee et al. [4,6], and Patel et al. [5] found that the protective effect of ebselen [3], PD150606 and E-64 (inhibitors of calpain activation) [4], interleukin-6 deficiency [5], and EUK-134 (a SOD and CAT mimetic) [6] in renal ischemia and reperfusion damage was associated with attenuation of nitrosative stress evaluated by tyrosine nitration. More recently it was shown that the protective effect of soy feeding of renal damage induced by puromycin aminonucleoside was associated with a decrease in tyrosine nitration [58].

Tyrosine nitration is induced by reactive nitrogen species including $\mathrm{ONOO}^{-}$which is synthesized by the reaction between superoxide anion $\left(\mathrm{O}_{2}^{\bullet \downarrow}\right)$ and nitric oxide $(\mathrm{NO})^{\bullet}$. The protective effect of ebselen, a $\mathrm{ONOO}^{-}$scavenger, in the IR-induced renal damage and tyrosine nitration suggests that $\mathrm{ONOO}^{-}$is enhanced and involved in tissue damage and nitrosative stress in this experimental model. There are evidences suggesting the increase of $\mathrm{O}_{2} \bullet \downarrow$ and $\mathrm{NO}{ }^{\bullet}$ in IR-induced renal damage [reviewed in [59]] which may favor ONOO- formation. In hypothyroid rats, the decreased nitrosative stress may be explained, at least in part, by the diminution in oxygen consumption and $\mathrm{O}_{2} \downarrow \downarrow$ production.

We wanted to know if the antioxidant enzymes may be involved in the protective effect of HTX in IR taking into 
Table 5: Effect of experimental hypothyroidism on oxidative stress markers.

\begin{tabular}{llll}
\hline Ref. & Specie & MHI & Change in oxidative stress markers \\
\hline 9 & Rat & HTX & $\leftrightarrow$ MDA and $\uparrow$ GSH in renal cortex. \\
50 & Rat & PTU & $\uparrow$ Brain total antioxidant status. \\
51 & Rat & PTU & $\downarrow$ MDA and GSH levels in cerebral, hepatic and cardiac tissues. \\
52 & Rat & PTU & $\uparrow$ Advanced glycation end-products and MDA-lysine in liver. \\
53 & Rat & HTX & $\uparrow$ GSH and $\downarrow$ MDA levels in liver. \\
54 & Rat & PTU & $\leftrightarrow$ MDA in plasma, erythrocytes, and liver tissue. \\
& & $\leftrightarrow$ GSH in levels of kidney and liver. \\
55 & Rat & Mouse & $\leftrightarrow$ Brain TBARS. \\
56 & Rat & PTU & $\leftrightarrow$ LPx and GSH, GSSG and GSSG/GSH ratio in skeletal muscle. \\
47 & PTU & $\downarrow$ TBARS in extensor digitorum longus muscle. \\
57 & Rat & $\leftrightarrow$ TBARS in heart, liver, and soleus muscle. \\
& & $\downarrow$ MTU &
\end{tabular}

Ref. = reference, $\mathrm{MHI}=$ Method of hypothyroidism induction, $\mathrm{HTX}=$ Thyroidectomized, $\mathrm{PTU}=$ 6-n-propyl-2-thiouracil, MMI = Methimazole, $\uparrow=$ increase, $\downarrow=$ decrease, $\leftrightarrow=$ without change, LPx = lipid peroxidation, MDA = malondialdehyde, GSH = reduced glutathione, GSSG = oxidized glutathione, TBARS $=$ Thiobarbituric acid reactive substances.

account several reports of the literature showing that the enhanced expression of some antioxidant enzymes was able to attenuate renal damage induced by IR $[11,16]$, $\mathrm{H}_{2} \mathrm{O}_{2}$ infusion [10,11], cisplatin [13], puromycin aminonucleoside [10], and cyclosporine A [15]. However, our data show that IR induced a decrease in the activity of CAT, GPx and SOD. Our data are consistent with previous data showing that renal ischemia and reperfusion damage is associated with a decrease in antioxidant enzymes $[19,20,60]$. Interestingly, the IR-induced decrease in antioxidant enzymes was not prevented by HTX in the HTX+IR group. In fact, in some cases, the IR-induced decrease in antioxidant enzymes was significantly higher in the HTX+IR group compared to IR group suggesting that these antioxidant enzymes are not involved in the protective effect of HTX on IR-induced renal damage and oxidative and nitrosative stress. Antioxidant enzymes activities in CT and HTX groups were essentially similar suggesting that hypothyroidism has no effect on the renal activity of these enzymes. There is no a consistent pattern on the effect of hypothyroidism on tissue antioxidant enzymes (see Table 6). Sawant et al. [67] found that SOD decreased, GPx increased and CAT remained unchanged in hypothyroid rats.

The most studied enzymes in hypothyroid animals are SOD, Cu, ZnSOD, MnSOD, CAT, GPx, and GR. The effect of hypothyroidism on the antioxidant enzymes in several tissues is not consistent (Table 6). In some cases the change of antioxidant enzyme activity seems to be tissue specific $[47,68]$. On the other hand, within a single tissue, the response of the antioxidant enzymes to hypothyroidism is not always similar [55,61-67].

Hypothyroidism attenuates not only renal but also cardiac damage induced by ischemia and reperfusion. Boba- dilla et al. [69] have shown that hypothyroidism conferred protection against reperfusion arrhythmias and the cardiac release of creatine kinase and aspartate amino transferase and preserved the normal structure of myocardial tissue. In addition Chavez et al. [70] demonstrated that hypothyroidism renders mitochondria resistant to the opening of membrane permeability transition pore. This may be relevant to the protective effect of hypothyroidism in ischemia and reperfusion since it has been recognized that mitochondria play a key role in cell-death pathways by activating mitochondrial permeability transition pore and causing the release of cytochrome $\mathrm{C}$ and proapoptotic factors, as well as $\mathrm{Ca}^{2+}$ overload that promotes non-selective permeability of the inner membrane. The prolonged opening of the membrane permeability transition pore during the first few minutes of reperfusion is a critical determinant of cell death, and pharmacological inhibition of the pore at the time of reperfusion protects the cells [71].

\section{Conclusion}

It is concluded that HTX rats are more resistant to oxidative and nitrosative stress and renal damage induced by $\mathrm{IR}$, which is not mediated by a differential regulation of the antioxidant enzymes CAT, GPx, and SOD.

\section{List of abbreviations used \\ ANOVA Analysis of variance}

BUN Blood urea nitrogen

CAT Catalase

CT Control rats

DNP Dinitrophenol 
Table 6: Effect of experimental hypothyroidism on antioxidant enzymes activities.

\begin{tabular}{|c|c|c|c|}
\hline Ref. & Specie & $\mathrm{MHI}$ & Change in antioxidant enzymes \\
\hline 61 & Rat & MMI & $\uparrow M n S O D$ and $C A T$ and $\leftrightarrow \mathrm{Cu}, \mathrm{ZnSOD}$ in brown adipose tissue. \\
\hline 62 & Rat & PTU & $\begin{array}{l}\text { In liver mitochondria: } \\
\uparrow \text { Total and Cu, ZnSOD, } \leftrightarrow \text { MnSOD, } \downarrow \text { CAT. } \\
\uparrow \text { Total and Se-independent and Se-dependent GPx }\end{array}$ \\
\hline 63 & Rat & PTU & $\downarrow$ SOD and $\leftrightarrow$ CAT in heart. \\
\hline 64 & Rat & MMI & $\uparrow \mathrm{GPx}, \leftrightarrow \mathrm{CAT}$, and total SOD in heart. \\
\hline 65 & Rat & PTU & $\downarrow \mathrm{SOD}$ and CAT and $\uparrow \mathrm{GPx}$ in testis. \\
\hline 66 & Rat & PTU & $\begin{array}{l}\text { In brain: } \\
\uparrow \text { Total and MnSOD, CAT, total and Se-dependent GPx. } \\
\downarrow \text { Se-independent GPx, and GR. }\end{array}$ \\
\hline 55 & Rat & MMI & $\begin{array}{l}\text { In cerebral cortex: } \\
\uparrow \text { Total SOD, Cu, ZnSOD, and GPx, and } \downarrow \text { MnSOD. } \\
\leftrightarrow \text { CAT. }\end{array}$ \\
\hline 67 & Rat & $\mathrm{Na}^{|3| \mid}$ & $\begin{array}{l}\downarrow \text { SOD, } \leftrightarrow \text { CAT, and } \uparrow \text { GPx in kidney. } \\
\downarrow \text { Plasma GPx. }\end{array}$ \\
\hline 47 & Rat & PTU & $\begin{array}{l}\mathrm{Cu}, \mathrm{ZnSOD} \leftrightarrow \text { in extensor digitorum longus and soleus muscles, } \uparrow \text { heart, and } \downarrow \text { liver. } \\
\mathrm{GPx} \leftrightarrow \text { in soleus muscle and liver } \uparrow \text { extensor digitorum longus muscle and heart. }\end{array}$ \\
\hline 68 & Rat & MMI & $\begin{array}{l}\text { GPx } \uparrow \text { in gastrocnemius muscle and heart, and } \leftrightarrow \text { in liver. } \\
\text { GR in } \leftrightarrow \text { heart, gastrocnemius muscle, and liver. }\end{array}$ \\
\hline
\end{tabular}

Ref. $=$ reference, $\mathrm{MHI}=$ Method of hypothyroidism induction, PTU = 6-n-propyl-2-thiouracil, MMI = methimazole, $\uparrow=$ increase, $\downarrow=$ decrease, $\leftrightarrow=$ without change, $\mathrm{SOD}=$ superoxide dismutase, $\mathrm{MnSOD}=$ manganese-dependent superoxide dismutase, $\mathrm{Cu}, \mathrm{ZnSOD}=$ copper,zinc-dependent superoxide dismutase, $\mathrm{Se}=$ selenium, $\mathrm{GPx}=$ Glutathione peroxidase, $\mathrm{GR}=$ glutathione reductase, $\mathrm{CAT}=$ catalase.

GPx Glutathione peroxidase

GR Glutathione reductase

GSH Glutathione, reduced form

GSSG Glutathione, oxidized form

4-HNE 4-hydroxy-2-nonenal

H\&E Hematoxylin-eosin

HTX Hypothyroid rats

IR Ischemia and reperfusion

MDA Malondialdehyde

MMI Methimazole

3-NT 3-nitrotyrosine

NBT Nitroblue tetrazolium

\section{ONOO-Peroxynitrite}

PTU 6-n-propyl-2-thiouracil,

ROS Reactive oxygen species

SD Standard deviation
SOD Superoxide dismutase

\section{Competing interests}

The author(s) declare that they have no competing interests.

\section{Authors' contributions}

VMTV performed ischemia and reperfusion studies, collected samples and measured the activity of antioxidant enzymes. DB performed histological and immunohistochemical analyses and edited the manuscript. MF thyroidectomized rats and characterized the hypothyroid state, performed ischemia and reperfusion studies and edited the manuscript. ET performed ischemia and reperfusion studies and edited the manuscript. RHP advised about the histological and immunohistochemical analyses. ONMC performed the statistical analyses and edited the manuscript. JPCH conceived and coordinated the study and wrote and edited the manuscript.

\section{Acknowledgements}

This work was supported by CONACYT 0359P-M to M Franco.

\section{References}

I. Nath KA, Norby SM: Reactive oxygen species and acute renal failure. Am J Med 2000, 190:665-678.

2. Pedraza-Chaverrí J, Tapia E, Bobadilla N: Ischemia-reperfusion induced acute renal failure in the rat is ameliorated by the spin-trapping agent $\alpha$-phenyl-N-tert-butyl nitrone (PBN). Ren Fail 1992, 1 4:467-47I.

3. Noiri E, Nakao A, Uchida K, Tsukahara H, Ohno M, Fujita T, Brodsky $\mathrm{S}$, Goligorsky MS: Oxidative and nitrosative stress in acute renal ischemia. Am J Physiol Renal Physiol 200I, 28 I:F948-F957. 
4. Chatterjee PK, Todorovic Z, Sivarajah A, Mota-Filipe H, Brown PA, Stewart KN, Mazzon E, Cuzzocrea S, Thiemermann C: Inhibitors of calpain activation (PDI 50606 and E-64) and renal ischemiareperfusion injury. Biochem Pharmacol 2005, 69: | |2|-||3|.

5. Patel NS, Chatterjee PK, Di Paola R, Mazzon E, Britti D, De Sarro A, Cuzzocrea $S$, Thiemermann $C$ : Endogenous interleukin-6 enhances the renal injury, dysfunction, and inflammation caused by ischemia/reperfusion. J Pharmacol Exp Ther 2005, 312:1170-1178.

6. Chatteriee PK, Patel NS, Kvale EO, Brown PA, Stewart KN, MotaFilipe H, Sharpe MA, Di Paola R, Cuzzocrea S, Thiemermann C: EUK134 reduces renal dysfunction and injury caused by oxidative and nitrosative stress of the kidney. Am J Nephrol 2004, 24:165-177.

7. Seth P, Kumari R, Madhavan S, Singh AK, Mani H, Banaudha KK, Sharma SC, Kulshreshtha DK, Maheshwari RK: Prevention of renal ischemia-reperfusion-induced injury in rats by picroliv. Biochem Pharmacol 2000, 59:1315-1322.

8. Adin CA, Croker BP, Agarwal A: Protective effects of exogenous bilirubin on ischemia-reperfusion injury in the isolated, perfused rat kidney. Am J Physiol Renal Physiol 2005, 288:F778-F784

9. Paller MS: Hypothyroidism protects against free radical damage in ischemia acute renal failure. Kidney Int 1986 29: II62-1166.

10. Kawamura T, Yoshioka T, Bills T, Fogo A, Ichikawa I: Glucocorticoid activates glomerular antioxidant enzymes and protects glomeruli from oxidant injuries. Kidney Int 199I, 40:29I-30I.

II. Yoshioka T, Bills T, Moore-Jarrett T, Greene HL, Burr IM, Ichikawa I: Role of intrinsic antioxidant enzymes in renal oxidant injury. Kidney Int 1990, 38:282-288.

12. Yoshioka T, Kawamura T, Meyrick BO, Beckman JK, Hoover RL, Yoshida $\mathrm{H}$, Ichikawa I: Induction of manganese superoxide dismutase by glucocorticoids in glomerular cells. Kidney Int 1994 45:21I-219.

13. Davis CA, Nick HS, Agarwal A: Manganese superoxide dismutase attenuates cisplatin-induced renal injury: importance of superoxide. J Am Soc Nephrol 200I, I 2:2683-2690.

14. Yin M, Wheeler MD, Connor HD, Zhong Z, Bunzendahl H, Dikalova A, Samulski RJ, Schoonhoven R, Mason RP, Swenberg JA, Thurman RG: Cu/Zn-superoxide dismutase gene attenuates ischemiareperfusion injury in the rat kidney. J Am Soc Nephrol 200I, | 2:269|-2700

15. Zhong Z, Connor HD, Yin M, Wheeler MD, Mason RP, Thurman RG: Viral delivery of superoxide dismutase gene reduces cyclosporine A-induced nephrotoxicity. Kidney Int 200I, 59:1397-1404

16. Shimizu H, Takahashi T, Suzuki T, Yamasaki A, Fujiwara T, Odaka $Y$, Hirakawa M, Fujita H, Akagi R: Protective effect of heme oxygenase induction in ischemic acute renal failure. Crit Care Med 2000, 28:809-8I7.

17. Deshane J, Wright M, Agarwal A: Heme oxygenase-I expression in disease states. Acta Biochim Pol 2005, 52:273-284.

18. Pedraza-Chaverrí J, Granados-Silvestre MA, Medina-Campos ON, Hernández-Pando R: Effect of the in vivo catalase inhibition on aminonucleoside nephrosis. Free Radic Biol Med 1999, 27:245-253.

19. Singh D, Chander V, Chopra K: Protective effect of catechin on ischemia-reperfusion-induced renal injury in rats. Pharmacol Rep 2005, 57:70-76.

20. Singh D, Chander V, Chopra K: Carvedilol attenuates ischemiareperfusion-induced oxidative renal injury in rats. Fundam Clin Pharmacol 2004, 18:627-634.

21. Aksoy Y, Yapanoglu T, Aksou H, Yildirim AK: The effect of dehydroepiandrosterone on renal ischemia-reperfusion-induced oxidative stress in rabbits. Urol Res 2004, 32:93-96.

22. Yokozawa T, Rhyu DY, Cho EJ, Aoyagi K: Protective activity of ()-epicatechin 3-O-gallate against peroxynitrite-mediated renal damage. Free Radic Res 2003, 37:56I-57I.

23. Rhyu DY, Yokozawa T, Choa EJ, Park JC: Prevention of peroxynitrite-induced renal injury through modulation of peroxynitrite production by the Chinese prescription Wen-Pi-Tang. Free Radic Res 2002, 36:126I-1269.

24. Tarpey MM, Wink DA, Grisham MB: Methods for detection of reactive metabolites of oxygen and nitrogen: in vitro and in vivo considerations. Am J Physiol Regul Integr Comp Physiol 2004, 286:R43I-R444.
25. Szabo C: Multiple pathways of peroxynitrite cytotoxicity. Toxicol Lett 2003, I40-141:105-II2.

26. Radi R: Nitric oxide, oxidants, and protein tyrosine nitration. Proc Natl Acad Sci USA 2004, I 1 I:4003-4008.

27. Barrera $D$, Maldonado PD, Medina-Campos ON, Hernández-Pando $R$, Ibarra-Rubio ME, Pedraza-Chaverrí J: HO-I induction attenuates renal damage and oxidative stress induced by $\mathrm{K}_{2} \mathrm{Cr}_{2} \mathrm{O}_{7}$. Free Radic Biol Med 2003, 34: 1390-1398.

28. Maldonado PD, Barrera D, Medina-Campos ON, Hernández-Pando R, Ibarra-Rubio ME, Pedraza-Chaverrí J: Aged garlic extract attenuates gentamicin induced renal damage and oxidative stress in rats. Life Sci 2003, 73:2543-2556.

29. Aksenov MY, Aksenova MV, Butterfield DA, Geddes JW, Markesbery WR: Protein oxidation in the brain in Alzheimer's disease. Neuroscience 200I, 103:373-383.

30. Toyokuni S, Uchida K, Okamoto K, Hattori-Nakakuki $Y$, Hiai $H$, Stadtman ER: Formation of 4-hydroxy-2-nonenal-modified proteins in the renal proximal tubules of rats treated with a renal carcinogen, ferric nitrilotriacetate. Proc Natl Acad Sci USA 1994, $91: 2616-2620$

3I. Zainal TA, Weindruch R, Szweda LI, Oberley TD: Localization of 4hydroxy-2-nonenal-modified proteins in kidney following iron overload. Free Radic Biol Med 1999, 26: II8I-1193.

32. Franco M, Galicia O, Quintana A, Martinez F: Experimental hypothyroidism modifies specific binding of $A I$ and A2A analogues to adenosine receptors in the rat kidney. $\mathrm{Br} J$ Pharmacol 2004, I 42:46|-468.

33. Franco M, Bobadilla NA, Suárez J, Tapia E, Sánchez L, Herrera-Acosta J: Participation of adenosine in the renal hemodynamic abnormalities of hypothyroidism. Am J Physiol 1996, 270:F254-F262

34. Franco M, Tapia E, Martinez F, Davila Ma E, Grimaldo Jl, Medina K, Herrera-Acosta J: Adenosine regulates renal nitric oxide production in hypothyroid rats. I Am Soc Nephrol 1999 , 10:1681-1688.

35. Martinez F, Franco M, Quintana A, Herrera-Acosta J: Sodiumdependent adenosine transport is diminished in brush border membrane vesicles from hypothyroid rat kidney. Pflugers Arch 1997, 433:269-275.

36. Pedraza-Chaverri J, Barrera D, Maldonado PD, Chirino YI, MaciasRuvalcaba NA, Medina-Campos ON, Castro L, Salcedo MI, Hernandez-Pando R: S-allylmercaptocysteine scavenges hydroxyl radical and singlet oxygen in vitro and attenuates gentamicininduced oxidative and nitrosative stress and renal damage in vivo. BMC Clin Pharmacol 2004, 4:5.

37. Pedraza-Chaverri J, Barrera D, Medina-Campos ON, Carvajal RC, Hernandez-Pando R, Macias-Ruvalcaba NA, Maldonado PD, Salcedo MI, Tapia E, Saldivar L, Castilla ME, Ibarra-Rubio ME: Time course study of oxidative and nitrosative stress and antioxidant enzymes in K2Cr207-induced nephrotoxicity. BMC Nephrol 2005, 6:4.

38. Chatterjee PK, Cuzzocrea S, Brown PA, Zacharowski K, Stewart KN, Mota-Filipe H, Thiemermann C: Tempol, a membrane-permeable radical scavenger, reduces oxidant stress-mediated renal dysfunction and injury in the rat. Kidney Int 2000, 58:658-673.

39. Lowry $\mathrm{OH}$, Rosenbrough NJ, Farr AL, Randall RJ: Protein measurement with the Folin phenol reagent. J Biol Chem 195I, 193:265-275.

40. Pedraza-Chaverrí J, Granados-Silvestre MA, Medina-Campos ON, Maldonado PD, Olivares-Corichi IM, Ibarra-Rubio ME: Post-transcriptional control of catalase expression in garlic treated rats. Mol Cell Biochem 2001, 216:9-19.

4I. Pedraza-Chaverrí J, Maldonado PD, Medina-Campos ON, OlivaresCorichi IM, Granados-Silvestre MA, Hernández-Pando R, lbarraRubio ME: Garlic ameliorates gentamicin nephrotoxicity: relation to antioxidant enzymes. Free Radic Biol Med 2000, 29:602-6II.

42. Isman CA, Yegen BC, Alican I: Methimazole-induced hypothyroidism in rats ameliorates oxidative injury in experimental colitis. J Endocrinol 2003, 177:47 I-476.

43. Rodriguez-Pierce M, Sosenko IR, Whitney P, Frank L: Propylthiouracil treatment decreases the susceptibility to oxygen radical-induced lung damage in newborn rats exposed to prolonged hyperoxia. Pediatr Res 1994, 35:530-535. 
44. Allen T, Rana SV: Oxidative stress by inorganic arsenic: modulation by thyroid hormones in rat. Comp Biochem Physiol C Toxicol Pharmacol 2003, 135:157-162.

45. Nishiki K, Ericinska M, Wilson DF, Cooper S: Evaluation of oxidative phosphorylation in hearts from euthyroid, hypothyroid and hyperthyroid rats. Am J Physiol 1978, 235:C212-C219.

46. Swaroo A, Ramasarma T: Heat exposure and hypothyroid conditions decrease hydrogen peroxide generation in liver mitochondria. Biochem J I985, 226:403-408.

47. Asayama K, Dobashi K, Hayashibe H, Megata Y, Kato K: Lipid peroxidation and free radical scavengers in thyroid dysfunction in the rat: a possible mechanism of injury to heart and skeletal muscle in hyperthyroidism. Endocrinology 1987, | 2 | :2 | | 2-2 | |8.

48. Bruck R, Frenkel D, Shirin H, Aeed H, Matas Z, Papa M, Zaidel L, Avni Y, Oren R, Halpern Z: Hypothyroidism protects rat liver from acetaminophen hepatotoxicity. Dig Dis Sci 1999, 44: I 228-I 235.

49. James LP, Mayeux PR, Hinson JA: Acetaminophen-induced hepatotoxicity. Drug Metab Dispos 2003, 3 I: | 499-I 506.

50. Carageorgiou H, Pantos C, Zarros A, Mourouzis I, Varonos D, Cokkinos $\mathrm{D}$, Tsakiris $\mathrm{S}$ : Changes in antioxidant status, protein concentration, acetylcholinesterase, $(\mathrm{Na}+, \mathrm{K}+)-$, and $\mathrm{Mg2+}$ ATPase activities in the brain of hyper- and hypothyroid adult rats. Metab Brain Dis 2005, 20:129-I39.

51. Mogulkoc R, Baltaci AK, Aydin L, Oztekin E, Sivrikaya A: The effect of thyroxine administration on lipid peroxidation in different tissues of rats with hypothyroidism. Acta Physiol Hung 2005 92:39-46.

52. Pamplona R, Portero-Otin M, Ruiz C, Bellmunt MJ, Requena JR, Thorpe SR, Baynes JW, Romero M, Lopez-Torres M, Barja G: Thyroid status modulates glycoxidative and lipoxidative modification of tissue proteins. Free Radic Biol Med 1999, 27:901-910.

53. Teare JP, Greenfield SM, Marway JS, Preedy VR, Punchard NA, Peters T], Thompson RP: Effect of thyroidectomy and adrenalectomy on changes in liver glutathione and malonaldehyde levels after acute ethanol injection. Free Radic Biol Med 1993, | 4:655-660.

54. Tas S, Dirican M, Sarandol E, Serdar Z: The effect of taurine supplementation on oxidative stress in experimental hypothyroidism. Cell Biochem Funct 2004 in press.

55. Mano T, Sinohara R, Sawai Y, Oda N, Nishida Y, Mokumo T, Asano K, Ito $Y$, Kotake M, Hamada M, Nakai A, Nagasaka A: Changes in lipid peroxidation and free radical scavengers in the brain of hyper- and hypothyroid aged rats. J Endocrinol 1995, | 47:36I-365.

56. Gredilla R, Lopez Torres M, Portero-Otin M, Pamplona R, Barja G: Influence of hyper- and hypothyroidism on lipid peroxidation, unsaturation of phospholipids, glutathione system and oxidative damage to nuclear and mitochondrial DNA in mice skeletal muscle. Mol Cell Biochem 200I, 22 I:4I-48.

57. Mogulkoc R, Baltaci AK, Oztekin E, Ozturk A, Sivrikaya A: Short therm thyroxine administration leas to lipid peroxidation in renal and testicular tissues of rats with hypothyroidism. Acta Biol Hung 2005, 56:225-232.

58. Pedraza-Chaverri J, Barrera D, Hernandez-Pando R, Medina-Campos ON, Cruz C, Murguia F, Juarez-Nicolas C, Correa-Rotter R, Torres $\mathrm{N}$, Tovar AR: Soy protein diet ameliorates renal nitrotyrosine formation and chronic nephropathy induced by puromycin aminonucleoside. Life Sci 2004, 74:987-999.

59. Ueda N, Mayeoux PR, Baliga R, Shah SV: Oxidant mechanisms in acute renal failure. In Acute renal failure. A companion to Brenner \& Rector's The Kidney Edited by: Molitoris BA, Finn WF. Philadelphia: WB Saunders; 2001:60-77.

60. Dobashi K, Ghosh B, Orak JK, Singh I, Singh AK: Kidney ischemiareperfusion: modulation of antioxidant defenses. Mol Cell Biochem 2000, 205: I-II.

61. Petrovic N, Cvijic G, Davidovic V: The activity of antioxidant enzymes and the content of uncoupling protein-I in the brown adipose tissue of hypothyroid rats: comparison with effects of iopanoic acid. Physiol Res 200I, 50:289-297.

62. Das K, Chainy GB: Modulation of rat liver mitochondrial antioxidant defence system by thyroid hormone. Biochim Biophys Acta 2001, 1537:1-13.

63. Chattopadhyay S, Zaidi G, Das K, Chainy GB: Effects of hypothyroidism induced by 6-n-propylthiouracil and its reversal by
T3 on rat heart superoxide dismutase, catalase and lipid peroxidation. Indian J Exp Biol 2003, 4I:846-849.

64. Mano T, Sinohara R, Sawai Y, Oda N, Nishida Y, Mokuno T, Kotake M, Hamada M, Masunaga R, Nakai A, Nagasaka A: Effects of thyroid hormone on coenzyme $Q$ and other free radical scavengers in rat heart muscle. J Endocrinol |995, |45:|3|-|36.

65. Choudhury S, Chainy GB, Mishro MM: Experimentally induced hypo- and hyper-thyroidism influence on the antioxidant defence system in adult rat testis. Andrologia 2003, 35:|3|-|40.

66. Das K, Chainy GB: Thyroid hormone influences antioxidant defense system in adult rat brain. Neurochem Res 2004, 29:1755-1766.

67. Sawant BU, Nadkarni GD, Thakare UR, Joseph LJ, Rajan MG: Changes in lipid peroxidation and free radical scavengers in kidney of hypothyroid and hyperthyroid rats. Indian J Exp Biol 2003, 4 I : I334-I337.

68. Venditti P, Balestrieri M, Di Meo S, De Leo T: Effect of thyroid state on lipid peroxidation, antioxidant defences, and susceptibility to oxidative stress in rat tissues. J Endocrinol 1997 , I55:|5|-|57.

69. Bobadilla I, Franco M, Cruz D, Zamora J, Robles SG, Chávez E: Hypothyroidism provides resistance to reperfusion injury following myocardium ischemia. Int J Biochem Cell Biol 200I, 33:499-506.

70. Chávez E, Franco M, Reyes-Vias H, Zazueta C, Ramírez J, Carrillo R: Hypothyroidism renders liver mitochondria resistant to the opening of membrane permeability transition pore. Biochim Biophys Acta 1998, I 407:243-248.

7I. Halestrap AP, Clarke SJ, Javadov SA: Mitochondrial permeability transition pore opening during myocardial reperfusion - a target for cardioprotection. Cardiovasc Res 2004, 6 I :372-385.

\section{Pre-publication history}

The pre-publication history for this paper can be accessed here:

http://www.biomedcentral.com/1471-2369/6/12/prepub
Publish with Biomed Central and every scientist can read your work free of charge

"BioMed Central will be the most significant development for disseminating the results of biomedical research in our lifetime. "

Sir Paul Nurse, Cancer Research UK

Your research papers will be:

- available free of charge to the entire biomedical community

- peer reviewed and published immediately upon acceptance

- cited in PubMed and archived on PubMed Central

- yours - you keep the copyright
BiolMedcentral 